\title{
EKSPERIMEN PEMBUATAN BELIUNG PERSEGI
}

\begin{abstract}
Ali Akbar
Abstract

Writing a research paper does not only use three steps, such as analysis, explanation and conclusion, but it may also use analogy. It assumes two phenomena, individual or inter-related, similar. Analogizing method uses historic, ethnographic, and experimental sources. Experimental analogy, in particular, is done by duplication. For example, it is conducted by making a stone tool, which implies that there is a collective knowledge about the characteristics of the raw material and their relations to human. Despite the fact that prehistoric archeological remnants, such as the rectangular adze, were found in different areas in Indonesia, there had not been many who knew about process of making them, and the people who used them. The experimental duplication was done repetitively, gradually, and systematically. Repetition of the production of rectangular adze is made in order to be able to draw a general conclusion. The raw materials that are used are chert, metalimestone, limestone, chalcedony, jasper, and obsidian. A rectangular adze is produced after some steps are taken: firstly, preparing the raw material and the tool, secondly, shaping, and thirdly, molding.
\end{abstract}

\section{Keywords}

Prehistoric stone tool, analogy, production process

\section{PENDAHULUAN}

Pada saat suatu peninggalan arkeologi prasejarah ditemukan, timbul beragam pertanyaan yang ingin dijawab agar dapat menghasilkan suatu penjelasan atau pengetahuan. Pertanyaan-pertanyaan tersebut tidak dapat dijawab oleh peninggalan arkeologi itu sendiri. Pertanyaan-pertanyaan itu juga tidak dapat dijawab oleh manusia pendukung peninggalan arkeologi tersebut karena manusia pendukungnya telah tiada. Oleh karena itu, pertanyaan-pertanyaan tersebut harus dijawab oleh arkeolog dengan melakukan suatu penelitian.

Selain berdasarkan analisis, penjelasan dan kesimpulan dapat pula dilakukan dengan analogi. Melalui analogi diasumsikan jika pada dua hal terdapat persamaan dasar atau hubungan antar dua fenomena, maka dua hal tersebut berarti sama (Malina dan Vašiček 1990, 223-4). Mundardjito menyatakan bahwa konsep analogi dijadikan landasan dengan asumsi bahwa jika dua kelompok gejala mempunyai kesamaan dalam 
hal tertentu, misalnya bentuk, maka keduanya akan memiliki kesamaan juga dalam beberapa hal lain, misalnya cara membuat dan cara memakai (Mundardjito 1981). Analogi adalah suatu metode yang bermanfaat dan peranannya tidak dapat dipungkiri lagi, sehingga hal yang terpenting adalah berupaya mengurangi kesalahan-kesalahan metodologis (Mundardjito 1981; Tanudirdjo 1987).

Analogi sedikitnya dapat bersumber dari data historis, data etnografi, dan data eksperimen. Data historis sulit sekali diterapkan di dalam penelitian prasejarah. Data eksperimen mengambil peranan penting terutama ketika tidak ada lagi suku bangsa yang dapat diteliti untuk menjawab permasalahan arkeologi. Mengingat peranannya yang penting, bahkan telah berkembang Arkeologi Eksperimental sebagai sebuah disiplin pada beberapa dekade yang lalu. Dalam perkembangannya tersebut, disiplin ini telah mengalami sejumlah kemajuannya yang luar biasa (Neustupny 1993, 171). Arkeologi eksperimental adalah istilah yang digunakan untuk menggambarkan sebuah usaha rekonstruksi sebuah proses di masa lalu dan percobaan hipotesa tentang cara manusia berhadapan dengan tantangan hidup dan teknologi.

Kegunaan analogi eksperimen peniruan, misalnya membuat peralatan dari batu, mengimplikasikan keseragaman pandangan tingkah laku sifat-sifat bahan baku dan manusia. Pemikiran ini mengasumsikan bahwa bahan-bahan baku dan manusia modern secara anatomi dan tindak-tanduknya dapat diperbandingkan secara langsung dengan bahan baku dan manusia masa lalu. Selanjutnya, hal-hal yang dilakukan eksperimen peniruan dicari kesamaannya dengan hal-hal yang terjadi di masa lalu untuk menjelaskan apa yang terjadi di masa lalu. Dengan demikian, peneliti dapat mengobservasi dalam waktu sekarang, misalnya pembuatan alat batu atau cara berhubungan antara manusia yang satu dengan manusia yang lain dalam berbagai hal yang luas yang diekspresikan dalam sifat dan distribusi bahan-bahan yang dibuat dan digunakan. Pada akhirnya ditemukan serta dikonfirmasikan hukum-hukum umum dengan mendeskripsikan hubungan-hubungan tersebut (Watson dkk. 1971, 50).

Disiplin arkeologi ini dilakukan justru dari minat orang-orang non-arkeolog yang hanya sebagian bertujuan ilmiah ${ }^{1}$. Banyak praktisi eksperimen meyakini bahwa mereka telah membuktikan beberapa tesis arkeologi seperti penggunaan kapak. Persuasi yang dilakukan oleh para pembuat eksperimen dikuatkan oleh fakta bahwa banyak dari mereka menggunakan peralatan prasejarah yang diambil dari koleksi arkeologis ${ }^{2}$. Pandangan ini

\footnotetext{
${ }^{1}$ Kebanyakan arkeolog, misalnya ahli tentang tembikar prasejarah, tidak dapat membuat jambangan meskipun hanya perkiraan. Akan tetapi, banyak para ahli di bidang-bidang lain, yaitu bidang kerajinan yang dapat membuat tiruan benda prasejarah. Terdapat pandangan bahwa memang bukan tugas arkeolog meniru barang-barang temuan, tetapi setidaknya hal ini menarik untuk dicatat bahwa yang berwenang atas paradigma tipologi atau arkeolog hampir tidak ada yang dapat memproduksi barang-barang yang sama, yaitu barang-barang prasejarah. Orang yang mempunyai pengetahuan dan kemampuan tersebut tinggal di luar komunitas arkeologi (Neustupny 1993, 171).

${ }^{2}$ Penggunaan alat asli (artefak) kadang digunakan oleh orang yang melakukan eksperimen untuk benar-
} 
tentunya telah memunculkan banyak kontroversi selama adanya perbedaan antara apa yang mungkin terjadi dan apa yang telah terjadi ${ }^{3}$.

Pada beberapa contoh eksperimen peniruan mungkin dibutuhkan waktu lama sebelum solusi yang dapat diterima ditemukan, tetapi kadang-kadang juga dapat cepat sekali. Seringnya penemuan yang cepat itu terjadi karena arkeolog tersebut menemukan detil penting selama kerja eksperimen mereka. Detil ini sulit untuk ditemukan pada basis yang hanya berdasarkan model teoritis. Bahkan banyak kondisi yang menunjukkan bahwa eksperimen tersebut dapat diamati dan dikontrol (Coles 1973, 13-8). Beberapa aspek eksperimen dapat dengan mudah dijumlahkan (Neustupny 1993, 172).

Secara keseluruhan eksperimen arkeologi memiliki peran yang penting dalam usaha merekonstruksi masa lalu. Eksperimen arkeologi menjadi sumber masa depan yang penting bagi model-model arkeologi terutama sejauh ini dalam mengetahui fungsi peninggalan arkeologi ${ }^{4}$ Bahkan Neustupny (1993:173) menegaskan bahwa eksperimen arkeologi merupakan sumber pararel dan model yang penting bagi arkeologi.

Salah satu peninggalan arkeologi prasejarah yang banyak ditemukan di Indonesia adalah beliung persegi (rectangular adze). Lebih dari 5.000 buah beliung persegi telah ditemukan di Pulau Jawa dan tentunya masih banyak lagi apabila dijumlahkan dengan temuan di pulau-pulau lainnya di Indonesia (lihat Foto 1). Akan tetapi, pengetahuan mengenai proses pembuatan alat batu ini masih tergolong minim. Artefak batu ini diperkirakan mulai diproduksi oleh manusia di Indonesia pada masa neolitik, yakni sekitar tahun 2.000 sebelum Masehi, sehingga sering disebut sebagai Neolithic adze. Pada masa neolitik atau sebelum manusia mengenal pengolahan logam, alat batu ini digunakan untuk menebang pohon dan membuat ukiran kayu. Pada saat digunakan, benda ini diikat ke gagangnya yang terbuat dari kayu dan dipergunakan sebagaimana penggunaan pacul masa kini. Hanya saja ukuran beliung persegi sebagai "mata pacul" tidak terlalu besar, yakni rata-rata 5-10 cm. Masyarakat masa kini tidak lagi membuat beliung persegi, oleh karena itu pengetahuan mengenai produksi alat ini masih sangat terbatas. Apabila dibandingkan dengan tembikar yang juga mulai dikenal oleh manusia

benar memastikan penggunaannya. Tentu saja hal ini menimbulkan polemik. Neustupny menyebut tindakan tersebut sebagai kebiasaan yang barbar (Neustupny 1993, 171).

${ }^{3}$ Satu hal yang sering dijadikan argumen untuk melemahkan peran eksperimen arkeologi adalah fakta bahwa agen personal eksperimen arkeologi berbeda dengan orang sesungguhnya di masa lalu. Di dalam melakukan eksperimen tentu saja peran aktif dilakukan oleh praktisi eksperimen atau manusia modern. Manusia masa lalu tidak mungkin dapat dilibatkan, meskipun dengan pengetahuan eksakta atas teknologi kuno, sumber-sumber kuno, kondisi sosial dan mental atas tindakan-tindakan manusia masa lalu (Neustupny 1993, 170-1).

${ }^{4}$ Salmon memberi contoh, misalnya bagaimana mengetahui bahwa fungsi dari yang disebut "lubang asap/ cerobong asap" adalah untuk mengeluarkan asap dari dalam rumah. Mungkin desainer rumah tersebut membuat cerobong tersebut untuk tujuan yang lain, sehingga fungsi sesungguhnya dari cerobong tersebut tidak diketahui. Percobaan api di dalam rumah, mungkin dapat meyakinkan bahwa asap dapat keluar dari rumah melalui cerobong (Salmon 1982). 
pada masa neolitik, tembikar masih diproduksi oleh masyarakat masa kini. Dengan demikian, peneliti masih dapat menyaksikan proses pembuatan tembikar dan mencoba merekonstruksi pembuatan tembikar masa neolitik dengan berbekal pengamatan pada masa kini.

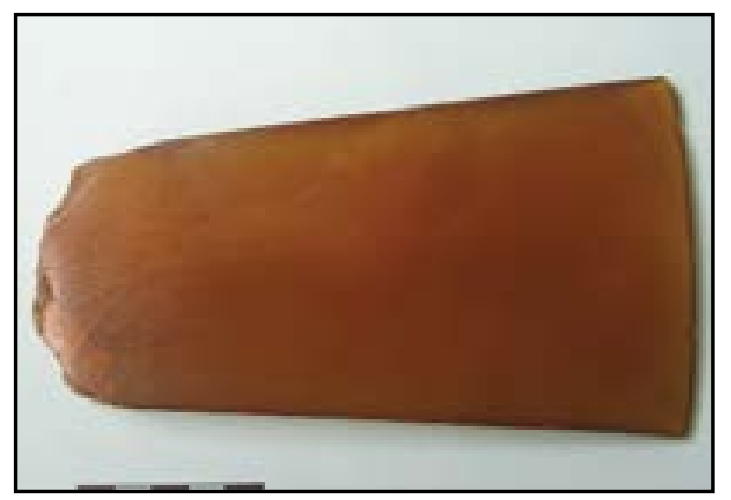

Foto 1. Salah satu beliung persegi dari Jawa

Foto: Ali Akbar

Di dalam penelitian ini dilakukan eksperimen pembuatan beliung persegi tiruan untuk membantu menjelaskan sejumlah perlakuan dan perilaku terhadap beliung persegi yang sudah tidak dapat diamati lagi karena masyarakat pendukungnya sudah tidak ada lagi.

\section{HASIL DAN PEMBAHASAN}

Penelitian mengenai proses pembuatan beliung persegi telah dilakukan oleh beberapa peneliti, misalnya P.V. van Stein Callenfels (1961) dan Hari Truman Simanjuntak (1983). Kedua peneliti tersebut mengambil kesimpulan berdasarkan tinggalan arkeologis. Sementara itu, eksperimen pembuatan alat batu yang dilakukan baik di dalam maupun di luar Indonesia umumnya untuk membuat alat batu paleolitik ${ }^{5}$. Penelitian dengan melakukan eksperimen pembuatan alat batu neolitik sejauh pengamatan penulis belum dilakukan.

Menurut Callenfels (1961:22-3), beliung persegi dihasilkan setelah melalui beberapa tahap kegiatan. Pada kegiatan pengumpulan bahan, dilakukan penarahan di sumber batuan untuk memperoleh bongkahan batu sebagai bahan baku (planche). Penelitian arkeologi di dekat sumber bahan biasanya menemukan pecahan-pecahan batu bekas tarahan serta planche yang tidak terpakai. Pada kegiatan pembentukan, titik berat pembuatan mengarah pada pembentukan bahan menjadi prabentuk. Bahan baku dibuat menjadi calon beliung persegi dengan dipangkas secara langsung dan tidak langsung 6

\footnotetext{
${ }^{5}$ Pembuatan alat batu telah dimulai pada masa paleolitik, yang kemudian masih dilanjutkan di masa mesolitik dan neolitik. Teknik pembuatan alat batu berupa teknik pukul dan teknik tekan telah dikenal sejak zaman paleolitik. Teknik tekan semakin banyak diterapkan pada masa mesolitik. Pada masa neolitik dikembangkan teknik baru, yakni teknik asah dan upam.

${ }^{6}$ Teknik pukul langsung (direct percussion) dilakukan dengan cara batu atau palu yang terbuat dari tulang atau kayu keras dipukulkan pada permukaan bahan baku yang ingin dibentuk. Pemangkasan dilakukan
} 
menggunakan pemukul dari batu atau ditekan dengan alat yang cukup keras, seperti kayu dan tanduk. Pada kegiatan penyelesaian akhir, calon beliung persegi diasah dan diupam $^{7}$ menjadi beliung persegi yang berpermukaan halus dan siap dipakai. Dalam mengasah dapat menggunakan berbagai cara, antara lain dengan menggunakan batu pasir sebagai alat pengasah dan untuk memperlancar proses pengasahan digunakan air. Dalam mengupam, beliung persegi yang sudah berpermukaan halus digosokkan pada alat yang lebih lunak seperti kayu atau bambu, sehingga diperoleh beliung persegi yang berpermukaan halus dan mengkilap (Callenfels 1961).

MenurutSimanjuntak (1983:66-7) proses produksi beliung persegi terbagi ke dalam 4 tahap. Tahap pertama atau tahap pendahuluan (preparing stage) berupa pengadaan bahan baku dan peralatan. Tahap kedua atau tahap pembentukan (forming stage) berupa pemangkasan awal untuk merubah bahan menjadi produk kasar. Limbah yang dihasilkan berupa batu serpihan dengan atau tanpa kulit batu (cortex). Tahap ketiga atau tahap pengerjaan kedua kali (dressing stage) untuk membentuk produk yang berpermukaan rata dengan pemangkasan ringan. Limbahnya berupa batu serpihan berukuran lebih kecil dibandingkan tahap kedua. Tahap keempat atau tahap pengerjaan akhir (finishing stage) membentuk bidang tajaman, penghalusan, dan pengupaman (polishing).

Eksperimen peniruan pembuatan beliung persegi dilakukan dengan mendapat bantuan dari 4 orang ahli yang terbiasa membuat alat batu paleolitik tiruan. Pertama, Dubel Driwantoro, seorang arkeolog yang menjadi peneliti di Pusat Penelitian Arkeologi Nasional. Kedua, Dayat, seorang teknisi di Balai Arkeologi Bandung. Ketiga, Ginarto seorang tenaga lokal yang sering diperbantukan dalam penelitian arkeologi di Pacitan. Keempat, Sigit Eko Prasetyo, seorang arkeolog yang menjadi pegawai magang di Balai Arkeologi Palembang. Keempat orang tersebut diminta bantuannya oleh penulis untuk melakukan pembuatan beliung persegi dengan berbagai tahapnya.

Ekperimen peniruan ini dilakukan secara berulang, bertahap, dan terarah. Pengulangan dilakukan agar kesimpulan yang ditarik merupakan suatu hal yang dapat dianggap umum di dalam produksi beliung persegi. Eksperimen peniruan dilakukan secara bertahap dimulai dari kegiatan mengumpulkan bahan baku hingga menghasilkan produk berupa beliung persegi jadi. Bahan baku yang digunakan adalah batuan chert, metalimestone, limestone, kalsedon, jasper, dan obsidian. Selain obsidian, batuan-batuan

dengan maksud melepaskan serpihan dari bahan baku. Teknik pukul tidak langsung (indirect percussion) menggunakan kayu atau tulang yang keras sebagai semacam pahat. Batu pukul dipukulkan ke kayu atau tulang yang diarahkan untuk memangkas calon alat batu. Teknik serpih tekan (pressure flaking) dilakukan dengan cara menekan calon alat batu dengan benda runcing seperti tulang atau tanduk yang keras, sehingga serpihan kecil akan terlepas dari batu tersebut. (Crabtree 1972; Oakley 1970; Howell 1982).

7 Teknik asah (abrading) berupa gerakan mengikis permukaan calon alat batu dengan batu lainnya yang lebih lunak, namun mampu mengikis calon alat (Jocano, tanpa tahun). Teknik upam (polishing) berupa gerakan mengusap calon alat yang telah dihaluskan permukaannya dengan menggunakan kulit bambu atau kulit hewan, sehingga menghasilkan permukaan yang mengilat (Callenfels 1961). 
tersebut cukup sering digunakan untuk membuat beliung persegi (Akbar 1999).

Eksperimen peniruan diarahkan untuk mengetahui proses pemilihan bahan baku, durasi atau lamanya proses produksi, kendala di dalam melakukan produksi, penerapan teknik pembuatan, limbah hasil produksi, dan produk yang dihasilkan. Berdasarkan eksperimen diketahui terdapat beberapa langkah yang harus dikerjakan untuk membuat beliung persegi tiruan, yaitu sebagai berikut.

\section{LANGKAH PERTAMA: PENGADAAN BAHAN BAKU DAN PERALATAN}

Langkah pertama dalam pembuatan beliung persegi adalah pengadaan bahan baku dan peralatan. Bahan baku yang digunakan pada percobaan peniruan pembuatan beliung persegi ini adalah Jasper, Chert, Silicifiedwood, Metalimestone, Kalsedon, Limestone, dan Obsidian. Bahan baku tersebut diperoleh dari berbagai tempat, misalnya di toko penjual tanaman dan perlengkapan taman di Jalan T. B. Simatupang di sekitar daerah Fatmawati dan Jalan Raya Lenteng Agung Jakarta Selatan. Peralatan yang digunakan adalah batu asah yang dibeli di toko bahan bangunan; kulit dan kain yang dibeli di toko; tulang kambing yang dibentuk sendiri supaya ada bagiannya yang runcing seperti pahat; dan batu pukul (hammer stone atau perkutor) dari batuan andesit dengan beragam ukuran, yaitu: besar, sedang, dan kecil.

Di dalam pencarian bahan baku ternyata tidak semua bahan baku mempunyai kualitas yang baik. Bahan baku yang dibeli di Jalan Raya Lenteng Agung umumnya telah lapuk sehingga batuannya menjadi tidak padu atau tidak kompak lagi. Batuan Silisifiedwood umpamanya dapat dipatahkan dengan menggunakan kedua belah tangan atau tanpa menggunakan alat pukul apa pun. Kemudian, pada batuan jasper yang sudah lapuk biasanya unsur hematit yang terdapat di batuan tersebut menjadi mudah terlepas dari batuan, oleh karena itu ketika dipegang batuan jasper akan meninggalkan bekas warna merah di tangan. Bahan baku yang telah lapuk bersifat rapuh sehingga tidak cocok untuk diolah lebih lanjut dalam pembuatan beliung persegi. Oleh karena itu, dipilih batuan yang masih segar sebagai bahan baku.

\section{LANGKAH KEDUA: PEMBENTUKAN BAHAN BAKU MENJADI CALON BELIUNG PERSEGI}

Setelah bahan baku terkumpul, maka langkah kedua adalah melakukan pembentukan untuk mengubah bahan baku menjadi calon beliung persegi. Pada bagian ini, terdapat dua tahap, yakni tahap pembentukan awal dan tahap pembentukan akhir. Pada tahap pembentukan awal dilakukan pemangkasan terhadap bahan baku yang dilakukan dengan menggunakan perkutor berukuran besar dan sedang. Pemangkasan dilakukan dengan teknik pukul langsung yang bertujuan untuk membentuk bahan baku menjadi bentuk segi empat. Sebuah bahan baku berukuran panjang sekitar $25 \mathrm{~cm}$ 
biasanya akan menghasilkan produk calon beliung persegi berukuran panjang sekitar 10 $\mathrm{cm}$. Selain produk calon beliung persegi, dihasilkan limbah berupa serpihan-serpihan berkorteks dan tidak berkorteks berukuran lebih dari $3 \mathrm{~cm}$ atau umumnya berukuran antara 5-10 cm (lihat Foto 2).

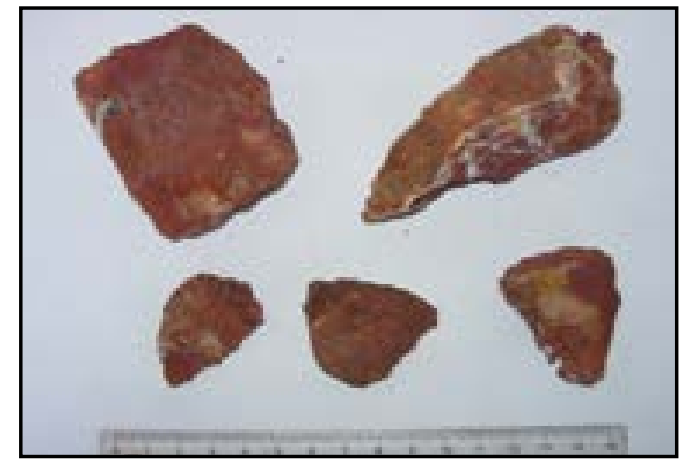

Foto 2. Limbah Berupa Batu Serpihan Ukuran Besar dan Sedang. Foto: Ali Akbar

Pada tahap ini ditemukan beberapa kesulitan yaitu pemangkasan terhadap kedua sisi bahan baku. Untuk memangkas kedua sisi digunakan perkutor berukuran sedang yang bertujuan untuk membentuk serta menipiskan bahan baku. Pada tahap ini sangat mungkin terjadi kegagalan pembuatan calon beliung persegi. Oleh karena itu, pemangkasan dilakukan dengan hati-hati dan dengan penuh kecermatan.

Pada percobaan peniruan, tidak terlalu sukar untuk memangkas bahan baku agar memiliki bentuk dasar segi empat. Namun, bentuk dasar segi empat ini masih memiliki ketebalan yang relatif besar, sehingga dilakukan pemangkasan untuk menipiskan bahan baku. Proses penipisan kadang membuat bentuk segi empat tersebut patah pada bagian tengah menjadi dua bagian atau lebih. Kegagalan dalam proses pembentukan awal ini kerap terjadi. Eksperimen yang dilakukan menunjukkan perbandingan lima banding satu. Maksudnya adalah dari lima bahan baku biasanya hanya satu yang dapat diolah lebih lanjut, sedangkan sisanya patah dan akhirnya menjadi limbah produksi. Hal ini terjadi karena dua kemungkinan. Kemungkinan pertama adalah terjadi kesalahan sudut pukul pada pemangkasan bahan baku. Kemungkinan kedua adalah kualitas bahan baku yang kurang baik.

Calon beliung persegi yang tidak patah biasanya memiliki kualitas bahan batuan yang lebih baik. Bahan baku yang kurang baik ditandai dengan sifat batuan yang tidak kompak, terdapat rongga, dan ada garis putih pada batuan. Rongga pada batu umumnya ditumbuhi semacam kristal kecil seperti butiran gula yang mengilat. Adanya rongga yang terdapat pada bagian dalam batuan membuat batuan mudah patah ketika dipangkas. Adanya rongga juga membuat bahan baku sulit dibentuk untuk menghasilkan beliung persegi yang berpermukaan rata. Selain rongga, juga terdapat semacam garis-garis berwarna putih di bagian dalam batu yang dapat memengaruhi hasil penyerpihan. Hal tersebut menyebabkan batuan mudah patah ketika dipukul dengan perkutor. Garis-garis berwarna putih disebut juga urat kuarsa. Bahan baku yang di dalamnya terdapat urat 
kuarsa.

Pada tahap ini pula, peralatan kadang mengalami kerusakan, misalnya perkutor. Kerusakan yang dimaksud adalah ujung batuan yang menjadi lokasi tumbukan menjadi terkelupas kulitnya. Bahkan, perkutor dapat pula patah sehingga tidak dapat digunakan lagi untuk memangkas. Pada umumnya, proses pengerjaan tahap pemangkasan awal ini memakan waktu sekitar 10-15 menit untuk setiap bahan baku. Produk akhir dari tahap pemangkasan awal berupa calon beliung persegi berbentuk segi empat dengan ukuran yang masih tebal dan belum ada bagian sisi tajaman.

Setelah pembentukan awal, dilakukan pembentukan akhir untuk menghasilkan calon beliung persegi yang memiliki permukaan relatif rata, tipis, dan telah ditentukan bagian tajamannya. Pada tahap ini dilakukan pemangkasan dengan menggunakan perkutor berukuran sedang dan kecil. Kegiatan pembentukan akhir menghasilkan limbah berupa batu serpihan berukuran kurang dari $3 \mathrm{~cm}$ atau lebih kecil dari tahap sebelumnya.

Pemangkasan yang dilakukan berupa pemangkasan ringan yang bertujuan untuk meratakan permukaan. Untuk itu, selain teknik pukul langsung digunakan pula teknik pukul tidak langsung dan teknik serpih tekan. Teknik pukul tidak langsung dan teknik tekan menggunakan alat berupa tulang kambing yang telah diruncingkan. Tulang ini, -- pada saat melakukan teknik pukul tidak langsung -- berfungsi sebagai pahat. Pada saat melakukan teknik tekan, tulang berfungsi sebagi alat penekan. Teknik pukul tidak langsung dan teknik tekan terutama digunakan karena pembuat beliung persegi dapat lebih leluasa memilih atau lebih tepat memangkas bagian yang dituju. Kedua teknik ini memiliki tingkat keakuratan yang lebih tinggi dibandingkan teknik pukul langsung.

Proses pengerjaan pada tahap akhir memakan waktu lebih lama daripada proses sebelumnya, yaitu 45 menit sampai 1 jam. Hal ini karena pemangkasan yang dilakukan sangat hati-hati agar tidak mengubah bentuk dasar calon beliung persegi tersebut. Produk yang dihasilkan pada kegiatan pembentukan akhir adalah calon beliung persegi yang memiliki bentuk dasar empat persegi panjang dan telah ditentukan bagian mata tajamannya (lihat Foto 3).

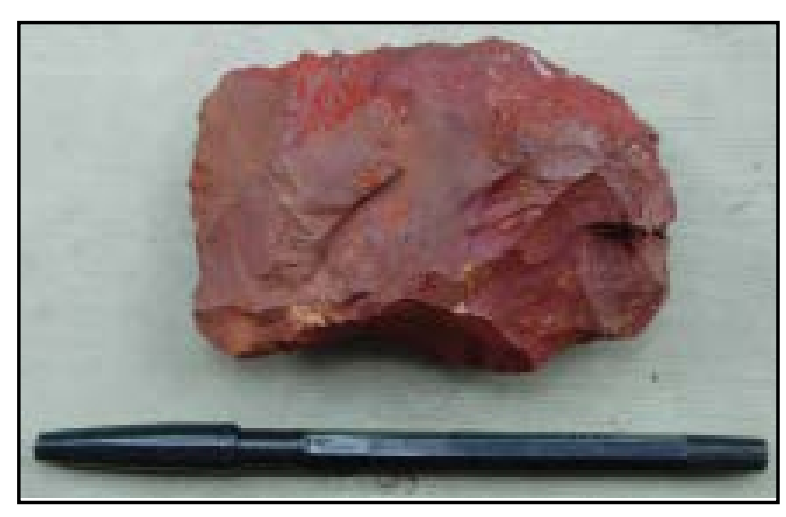

Foto 3. Calon Beliung Persegi Telah Ditentukan Mata Tajamannya. Foto: Ali Akbar 


\section{LANGKAH KETIGA: PEMBENTUKAN CALON BELIUNG PERSEGI MENJADI BELIUNG PERSEGI}

Langkah terakhir dalam proses produksi beliung persegi adalah penghalusan dan pengupaman. Penghalusan dan pengupaman dilakukan untuk mengubah bentuk calon beliung persegi menjadi beliung persegi. Pada bagian akhir ini diperlukan batu asah dan air untuk mengasah dan mengupam calon beliung persegi. Pengupaman beliung persegi juga dapat ditambah dengan menggunakan kain dan kulit.

Teknik yang dilakukan pada tahap ini adalah teknik asah (abgrading) dan upam (polishing). Pemilihan batu asah menjadi sangat penting di dalam kegiatan ini. Batu asah yang terlalu lunak tidak dapat menghaluskan permukaan calon beliung persegi, demikian pula dengan batu asah yang terlalu keras akan membuat permukaan calon beliung persegi berubah bentuk dasarnya. Cara untuk mengasah yang lebih efektif adalah dengan menaruh batu asah di permukaan tanah dengan calon beliung persegi berada di atasnya. Gerakan yang dilakukan adalah maju dan mundur atau menjauhi dan mendekati tubuh si pembuat. Gerakan ini diselingi dengan membasuh calon beliung persegi dan batu asah dengan air untuk menghilangkan limbah yang menempel pada batuan.

Gerakan maju dan mundur di atas membuat permukaan calon beliung persegi dan batu asah sama-sama menjadi terkikis. Batu asah biasanya berupa batupasir (sandstone). Akibat pengikisan adalah berkurangnya ukuran calon beliung persegi. Berdasarkan eksperimen ini diketahui bahwa batu asah mudah sekali terkikis, satu batu asah berukuran panjang $15 \mathrm{~cm}$, lebar $5 \mathrm{~cm}$, dan tebal $5 \mathrm{~cm}$ biasanya hanya dapat digunakan untuk mengasah tiga atau empat buah calon beliung persegi berukuran panjang $10 \mathrm{~cm}$.

Hasil dari kegiatan pengasahan ditandai dengan bertambah halusnya permukaan calon beliung persegi. Pengasahan yang dilakukan dalam waktu 20 menit dapat mengikis permukaan calon beliung persegi setebal 1,5 $\mathrm{mm}$. Limbah yang dihasilkan adalah butiran yang sangat kecil seperti lumpur halus. Proses pengasahan terkadang telah dapat menghasilkan beliung persegi yang permukaannya mengilat. Untuk menghasilkan permukaan yang lebih mengilat digunakan kain atau kulit yang diusap ke permukaan produk. Secara umum, sebuah calon beliung persegi diasah dan diupam selama tiga hari untuk menghasilkan beliung persegi.

Selain menggunakan bahan baku yang memang digunakan untuk membuat beliung persegi, dilakukan pula percobaan dengan menggunakan bahan baku lain, yakni obsidian. Eksperimen menunjukkan bahwa dari empat buah bahan baku obsidian yang rencananya dijadikan alat, hanya satu yang akhirnya menjadi calon beliung persegi. Satu buah yang tersisa pun mempunyai tebal yang cukup besar, sehingga ketika ditipiskan bentukan ini menjadi patah. Kesulitan yang dialami saat melakukan eksperimen adalah meskipun pembuat mampu untuk menentukan tempat yang akan dipangkas, hasil pangkasan tidak dapat diprediksi. Hasil pangkasan tidak dapat dikontrol karena obsidian 
mirip seperti kaca yang ketika dipukul menjadi hancur tidak beraturan. Kadang satu buah pukulan mengakibatkan bahan baku pecah berkeping-keping. Selain itu, obsidian tidak dapat diasah atau dihaluskan dengan batu asah. Kenyataan ini membuat cekungan atau tanda-tanda bekas pukul tidak dapat dihilangkan.

\section{KESIMPULAN}

Berdasarkan hasil eksperimen di atas, dapat disimpulkan bahwa beliung persegi dihasilkan setelah melalui beberapa tahap atau langkah. Kesimpulan tersebut apabila dijadikan data analogi dan dibandingkan dengan kesimpulan penelitian Callenfes dan Simanjuntak menunjukkan kesesuaian atau persamaan. Secara umum, sebuah beliung persegi dapat dihasilkan setelah melalui beberapa langkah, yaitu (1) pengadaan bahan baku dan peralatan; (2) pembentukan bahan baku menjadi calon beliung persegi, dan (3) pembentukan calon beliung persegi menjadi beliung persegi. Langkah terakhir inilah yang paling membedakan proses produksi alat batu neolitik dibandingkan alat batu masa sebelumnya.

Hasil eksperimen juga menunjukkan beberapa hal yang sulit diketahui atau dijelaskan dengan melakukan analisis terhadap peninggalan arkeologi. Beberapa di antaranya adalah sebagai berikut.

1. Tidaksemuabatuan dapat digunakan untuk membuat beliung persegi. Batuan obsidian, misalnya, meskipun telah digunakan untuk membuat alat pada masa sebelumnya, namun sifat pecahan obsidian membuatnya sulit dibentuk menjadi beliung persegi.

2. Di dalam proses pengasahan dibutuhkan cukup banyak air atau bahkan jumlah air harus melimpah. Selain itu, dibutuhkan batu asah dalam jumlah yang cukup banyak.

3. Untuk dapat menghasilkan sebuah beliung persegi sedikitnya dibutuhkan waktu selama tiga hari. Untuk memudahkan pembuatan, produsen tampaknya menetap di suatu tempat produksi.

4. Tidak setiap orang dapat membuat beliung persegi. Produsen beliung persegi sedikitnya harus memiliki kekuatan, kecermatan, kesabaran, dan sentuhan keindahan untuk dapat membuat produk tersebut.

Hasil eksperimen dapat menjadi data analogi yang selanjutnya digunakan untuk beberapa kepentingan, yaitu sebagai berikut. Pertama, menguji kesimpulan atau hipotesis penelitian sebelumnya. Kedua, membuat kesimpulan atau hipotesis untuk diuji di dalam penelitian berikutnya. Kedua hal tersebut umumnya lebih mengarah ke pernyataan sesuai atau tidak sesuai, setuju atau tidak setuju, atau sesuatu yang sifatnya benar atau salah. Berdasarkan penelitian ini, pada hemat penulis, hasil eksperimen juga dapat digunakan untuk melengkapi hasil penelitian sebelumnya yang mungkin hanya berdasarkan hasil analisis terhadap peninggalan arkeologi. Oleh karena itu, kepentingan yang ketiga-sebagai pengembangan poin pertama-adalah melengkapi kesimpulan atau hipotesis penelitian sebelumnya. Dengan demikian, eksperimen mempunyai 
kedudukan yang sejajar dengan analisis. Sebagai konsekuensi logisnya, di dalam suatu penelitian arkeologi selain dilakukan analisis - untuk hal-hal yang memungkinkanjuga dilakukan eksperimen.

\section{DAFTAR ACUAN}

Akbar, Ali. "Analisis Bahan Beliung Persegi dari Daerah Aliran Sungai Ciliwung". Skripsi. Depok: Fakultas Sastra Universitas Indonesia. 1999.

Callenfels, P. V. van Stein. Pedoman Singkat Koleksi Prasejarah Museum Pusat Lembaga Kebudayaan Indonesia. Cetakan Kelima. R. P. Soejono (terj.). Jakarta: Proyek Rehabilitasi dan Perluasan Museum DKI Jakarta. 1961.

Coles, John. Archaeology by Experiment. New York: Charles Scribner's Sons. 1973.

Crabtree, Don E. "An Introduction to Flintworking", Occasional Papers of the Museum Idaho State University. No. 28. Idaho: Idaho State University. 1972.

Howell, F. Clark. Manusia Purba (terj.). Pustaka Alam Life, Tira Pustaka Jakarta. 1982.

Jocano, F. Landa. An Anthropological Overview of the Beginnings of Filipino Society and Culture. Manila: Community Publishers, Inc. Tanpa Tahun.

Malina, Jaroslav and Zdeněk Vašiček. Archaeology Yesterday and Today: The Development of Archaeology in the Sciences and Humanities. Marck Zvelebil (terj. dan ed.). Cambridge: Cambridge University Press. 1990.

Mundardjito. “Etnoarkeologi: Peranannya dalam Pengembangan Arkeolog Indonesia", dalam Majalah Arkeologi Tahun IV No. 1-2 (1981): 17-29. Jakarta: Lembaga Arkeologi Fakultas Sastra Universitas Indonesia.

Neustupny, Evzen. Archaeological Method. Cambridge: Cambridge University Press. 1993.

Oakley, Kenneth P. Man the Tool-maker. London: Trustees of the British Museum National History. 1972.

Salmon, Merrilee H. Philosophy and Archaeology. London: Academic Press, Inc. 1982.

Simanjuntak, Hari Truman. "Situs Perbengkelan Limbasari, Purbalingga" Rapat Evaluasi Hasil Penelitian Arkeologi, 64-72. Yogyakarta: Puslit Arkenas. 1983.

Tanudirdjo, Daud Aris. Laporan Penerapan Penelitian Etnoarkeologi di Indonesia. Yogyakarta: Fakultas Sastra Universitas Gadjah Mada. 1987.

Watson, Patty Jo, Steven A. LeBlanc, Charles L. Redman. Explanation In Archaeology: An Explicitly Scientific Approach. New York: Columbia University Press. 1971. 